or by building extra rockets. Although there are bound to be fluctuations in a power's estimate of its strategic advantage, on the whole its strength and that of its adversary are likely to converge. What the nuclear powers are afraid of is that this comfortable security, as it may be thought, may be upset by new technical developments. To outsiders, however, one way of tying the hands behind the back may be as good as another. In particular, if the objective is some halt to the pace of new developments in arms technology, the chances are that making the test ban. comprehensive and in particular preventing the under- ground explosions of nuclear weapons which have characterized the past few years would serve just as well as the less tangible restrictions being talked about at Helsinki. None of this implies that the new talks are valueless - they may yet achiove something grander than anybody has dared to hope and the fact that they are taking place at all is something to be glad of. But if the nuclear powers were really dedicated to the view that arms control is a pragmatic and hard-headed discipline, they would quickly settle for a comprehensive test ban and then see what happened next.

\title{
Shotgun Marriage in Civil Aviation
}

Proposals announced last week by the government (HMSO, Cmnd 4213, $3 s 6 d$ ) for the future of civil aviation may well lead to the sensible and long overdue merger between BEA and BOAC. The intention is gradually to remove the individuality of the two companies by making them jointly responsible to an Airways Board charged with the task of making sure that the fleets and routes of BEA and BOAC are planned and marketed to the best advantage. Although the overt intentions of the White Paper are that the airlines should retain their individual identities, the fact that they will both lose their chairmen and be managed by the same board could well mean that they are quickly indistinguishable.

The advantages of bringing public sector airlines together include greater cooperation, and consequently less duplication of resources, in engineering studies of future aircraft and flight systems, industrial relations, catering, transport, training, inclusive tours and hotels. But the most welcome result will be that $\mathrm{BOAC}$ will become predominantly a long-haul airline, while BEA will eoncentrate on short flights. The White Paper has accepted the fact that separate planning of routes does not necessarily achieve the optimum result, and that the use of BOAC's long-haul aireraft on some short routes where traffic is dense could well pay off.

The independent airlines will not be so pleased with the White Paper. Not only docs it mean that they will face stronger competition from the state airlines, particularly on the shorter routes, but the paper also calls for the setting up of a Civil Aviation Authority to regulate the whole economic, technological and operational environment of the industry. This body will deal with public and private airlines on the same basis, and will be responsible for licensing routes. This will inevitably mean that some independent airlines must merge if they are to get a look in, and some of the more inefficient companies will be forced out of existence. An ominous warning to the independent airlines is that the government will only support a second carrier on routes where it would not unduly harm the corporations.

The White Paper is not so decisive about pricing policics. The government accepts the principle that a more rational price structure is necessary, and that this should be related as closely as possible to costs, but, before any idea of abandoning the international cartel system is inferred, the White Paper says that no ready alternative to the mechanism of the International Air Transport Association is available. The obvious approach to pricing policy is therefore a more vigorous pursuit of government intentions at the conference table of IATA. This does not preclude, however, the cross-subsidization by existing profitable services of new routes that are in the development stage. The White Paper also accopts the need for minimum prices for some inclusive tour holidays to give adequate protection to competing services, and to ensure that cut-price tours must measure up to safety requirements. The distinction between scheduled and non-scheduled routes is changing, however, and the acceptance of the need to look at every case individually could lead to a reduction in fares, especially for off-peak travel.

\section{RABIES \\ Is Quarantine Enough?}

'The Pets' Country Club in Folkestone has just produced its third rabid dog in four months. While an inquiry was under way into the saga of Fritz of Camberley (see Nature, 224, 634; 1969), the Ministry of Agriculture announced that a labrador called Whisky had died in the Folkestone quarantine kennels three days before it was due to be released, and asked its inquiry team to report on the origins of this case too. Both Fritz (which died two weeks after coming out of quarantine) and Whisky came from West Germany, but until the reports appear it will not be possible to know whether the dogs brought the disease with them or contracted it in the kennels.

The British quarantine arrangements seem to be foolproof. Anyons who wants to import a feline or canine animal, dog or tiger, has to apply for a licence to the Animal Health Division of the Ministry of Agriculture. When the animal arrives in Britain, officially recognized agents transport it from airport or quayside to officially approved kennels such as the Pets' Country Club, where it spends six months; special arrangements are made for larger animals on their way to zoos. There are about forty-five kennels and catteries in England and Wales, which in 1967 received about 4,750 cats and dogs-three dogs for 
every two cats. While in quarantine, animals are kept isolated and dogs are exercised separately. In these conditions, it is difficult to see how cross-infection could occur.

In an island free from rabies, the possibility of illegal importation must be reckoned with. Since 1919, more than 77,000 animals have been quarantined, and of these only thirty-two dogs and one leopard have gone rabid. On a large continent where the virus has infected wild life, however, border controls are clearly insufficient. Foxes in particular can transmit rabies very quickly from one country to another, and can spread the disease to domestic animals, evading all measures to keep dogs apart from one another.

This is what has happened in Europe during the last twenty years. Although most countries now require animals to be vaccinated before they are imported, the incidence of rabies has still increased. In West Germany, for example, the number of known cases rose from 1,400 in 1954 to 3,700 in 1966 , but up to two-thirds of these each year were among foxes. Dogs accounted for only about 5 per cent of the total. One measure widely used has been to vaccinate all dogs living within 20 to $40 \mathrm{~km}$ of a frontier with an area where rabies is in the natural environment, but the result is reduction rather than eradication.

The question arising from the British cases is whether six months' quarantine is long enough. Two dogs died after being in the country for about six months, and in any case the incubation period is notoriously uncertain. The virus can also be carried without any symptoms appearing. On the other hand, it has not yet been proved that the cases were unconnected. All dogs released from the relevant block of the Folkestone kennels since July are now under restriction and can only be exercised if muzzled and on a lead, so that if rabies has spread among them it will at least be contained.

\section{PROCESS PLANT}

\section{loy through Strength}

THE view that the British process plant industry should be organized in larger units is the dominating theme of the report of the expert committee which has been investigating the industry for the Ministry of Technology (HMSO, $3 s 6 d$ ). The report was promptly blessed by Mr Anthony Wedgwood Benn, the Minister of Technology, when it appeared this week. Mr Benn said that he had already met the Central Electricity Board, the Gas Council and three large industrial companies to discuss some of the implications.

The process plant industry has been an object of public sympathy ever since the exceptional demand for process plant equipment in the period centred on 1966 showed up the inadequacy of the plant manufacturers. One of the obvious difficulties, repeatedly referred to in the report, is that most of the manufacturers are comparatively small, with an annual turnover of between $£ 0.25$ and $£ 1.5$ million. But the Expert Committee also complains that there is too little coordination between users, contractors and manufacturers, that the larger process industries and particularly the large chemical companies have left the manufacturers and contractors behind technologically, that the plant manufacturers are by comparison poorly managed and unspecialized, and that both contractors and plant manufacturers are too small to have made headway in "breaking the virtual monopoly" of American contractors in the oil refinery business.

The Expert Committee advocates the familiar doctrine of rationalization as a cure. The Industrial Reorganization Corporation is urged to help bring about mergers, but the committee also asks that "the boards of leading companies in each sector of the plant manufacturing industries should urgently consider ... how to bring about the emergence of a small number of more efficient larger groupings deploying greater resources". One of the objectives, it says, should be to create a financial base large enough to support a meaningful programme of research and development. Another should be to recruit skilled and modern managers. The same recipe is offered the process plant contractors. They, too, should merge and, with the manufacturers, should pay attention to the need for better quality and more rapid delivery of raw materials, particularly special steels. As a spur to all concerned, the Expert Committee urges that nationalized industries and the larger users of process plant should make more use of their power as large buyers to encourage "the better and more forward looking manufacturers and to squeeze out the poorer ones".

This may be recognized as an echo of the present government's election manifesto in 1964, but the Expert Committee comes out against a state supported industry. On the other hand, the committee does consider that the process plant manufacturers and contractors could usefully link up with organizations abroad. The Ministry of Technology is told that useful work might be done by providing risk insurance for promoting commercial uses of new plant and processes. Coming as it does on the heels of several reports of the Working Party sponsored by the old Department of Economic Affairs, the new document should at least convince the industry that something needs to be done.

\section{PARTICLE ACCELERATORS}

\section{All Set for CERN Decision}

Tre decision by the French Government last week to confirm its earlier commitment to the CERN $300 \mathrm{GeV}$ accelerator makes it almost certain that the council of CERN will finally decide to go ahead with the project when it next meets on December 18. French participation had been cast in doubt by the decision of the British Government in 1967 not to participate. Now France joins Austria, Belgium, Italy, West Germany and Switzerland among those faithful to the accelerator.

If the $300 \mathrm{GeV}$ project is ratified next month, the CERN council will have five sites to choose from, one in each of the participating countries except Switzerland. The accelerator is expected to take eight years to build at a cost at 1969 prices of 1,431 million Swiss francs (about $£ 140$ million). Of this, SFr 934 million will be spent on the accelerator itself, SFr 288 million on laboratories and services and SFr 209 million on preparatory experiments. The largest contributions will be from West Germany (36 per cent) and France (30 per cent).

If the project goes ahead, the British government will no doubt come under renewed pressure to join. The financial contributions for the first two years 